\title{
INTENSITAS COPYING ANSWER PADA TES KEMAMPUAN MATEMATIKA
}

\author{
Nursalam \\ Fakultas Tarbiyah dan Keguruan UIN Alauddin Makassar \\ Kampus II: Jalan Sultan Alauddin Nomor 36 Samata-Gowa \\ Email: salam_uin@yahoo.com
}

\begin{abstract}
Abstrak:
Seorang peserta tes akan menjawab tes dengan tiga asumsi yaitu peserta tes akan menjawab suatu butir pertanyaan karena mengetahui, peserta menjawab tes dengan menebak, dan peserta menjawab tes karena menyalin jawaban dari peserta lain (menyontek). Akan tetapi jika peserta tes tidak memiliki akses untuk menyontek maka peserta hanya akan memberikan jawaban dengan asumsi pertama dan kedua. Artikel ini membahas intensitas menyontek sebelum pelaksanaan tes, pada saat pelaksanan tes, dan ketika tes dilaksanakan secara tiba-tiba. Hasil penelitian menunjukkan bahwa intensitas menyontek paling tinggi dilakukan oleh peserta tes pada saat ujian berlansung kemudian ketika ujian dilakukan secara tiba-tiba atau mendadak dan terakhir adalah sebelum pelaksanaan tes.
\end{abstract}

\begin{abstract}
:
A test taker would answer a test with three assumptions; she/he will answer the question items because of knowing, by guessing, and copying the answers from other participants (cheating). However, if the test taker does not have any access to cheat, she/he will only give answers using the first and second assumptions. This article discusses the intensity of cheating before conducting test, during taking the test, and when the tests are carried out suddenly. The results showed that the highest intensity of cheating is done by the test takers during examinations, then when the test is done suddenly and the last before taking the test.
\end{abstract}

Kata kunci:

Cheating, copying answer, test, intensitas menyontek

SALAH satu hal yang harus diperhatikan sebelum pelaksanaan tes, agar menghasilkan hasil yang maksimal adalah security tes. Masalah pengamanan tes yang dimaksudkan adalah mulai dari instrumen tes yang harus terjaga dengan baik sampai kepada pelaksanaan tes itu berlangsung. Hal ini dilakukan dengan harapan agar setiap peserta tes tidak melakukan praktik-praktik kecurangan.

Cheating (menyontek) merupakan perbuatan yang menggunakan cara-cara yang tidak sah untuk tujuan yang sah/terhormat yaitu mendapatkan keberhasilan akademis atau menghindari kegagalan akademis. Upaya yang dilakukan seseorang untuk mendapatkan keberhasilan dengan cara-cara yang tidak adil. Dengan demikian, cheating itu menjadi hal yang dilarang dalam pelaksanaan ujian dalam bentuk apapun. Karena jika hal ini terjadi maka ujian yang dilaksanakan akhirnya tidak mampu mengukur ketercapaian kompetensi lulusan.

Kecurangan dalam pelaksanaan ujian merupakan masalah klasik karena telah dilakukan sejak dahulu dan bahkan menjadi budaya hingga saat ini. Beberapa pene- 
litian telah dilakukan terkait dengan kecurangan dalam ujian yaitu Stainer mengemukakan bentuk-bentuk kecurangan dan ketidakjujuran dalam pelaksanaan ujian adalah menyalin jawaban dari bagian belakang kartu, menyalin pekerjaan temannya, keliru menulis apa yang dilihat, didengar, atau dilakukan. ${ }^{1}$ Penelitian lain yang dilakukan oleh Bushway menyatakan bahwa kecurangan di dalam kelas meliputi banyak perilaku di antaranya menggunakan buku catatan pada saat ujian, menyalin jawaban dari pekerjaan siswa yang lain, membiarkan orang lain menyalin pekerjaan rumah, dan menjiplak. ${ }^{2}$

Ada beberapa bentuk cheating di antaranya meniru pekerjaan teman atau menyontek (copying answer), bertanya langsung pada teman ketika sedang mengerjakan tes/ujian, membawa catatan pada kertas, pada anggota badan atau pada pakaian masuk ke ruang ujian, menerima kiriman jawaban dari pihak luar, mencari bocoran soal, arisan (saling tukar) mengerjakan tugas dengan teman, perjokian, memberi lilin atau pelumas kepada lembaran jawaban komputer atau menebarkan atom magnit dengan maksud agar mesin scanner komputer dapat terkecoh ketika membaca lembar jawaban sehingga gagal mendeteksi jawaban yang salah atau menganggap semua jawaban benar. ${ }^{3}$

Beberapa alasan siswa melakukan cheating adalah karena terpengaruh setelah melihat orang lain melakukan cheating meskipun pada awalnya tidak ada niat melakukannya, terpaksa membuka buku karena pertanyaan ujian terlalu tekstual (buku sentris) sehingga memaksa peserta ujian harus menghafal kata demi kata dari buku teks, merasa dosen/guru kurang adil dan diskriminatif dalam pemberian nilai, adanya peluang karena pengawasan yang tidak ketat. Takut gagal artinya yang bersangkutan tidak siap menghadapi ujian tetapi tidak mau menundanya dan tidak mau gagal. Ingin mendapatkan nilai tinggi tetapi tidak bersedia mengimbangi dengan belajar keras atau serius. Tidak percaya diri meskipun siswa bersangkutan sudah belajar teratur tetapi ada kekhawatiran akan lupa lalu akan menimbulkan kefatalan, sehingga perlu diantisipasi dengan membawa catatan kecil. Terlalu cemas menghadapi ujian sehingga hilang ingatan sama sekali lalu terpaksa buka buku atau bertanya kepada teman yang duduk berdekatan. Merasa sudah sulit menghafal atau mengingat karena faktor usia, sementara soal yang dibuat penguji sangat menekankan kepada kemampuan mengingat. Mencari jalan pintas dengan pertimbangan daripada mempelajari sesuatu yang belum tentu keluar lebih baik mencari bocoran soal, menganggap sistem penilaian tidak objektif, sehingga pendekatan pribadi kepada dosen/guru lebih efektif daripada belajar serius. Penugasan guru/dosen yang tidak rasional yang mengakibatkan siswa/mahasiswa terdesak sehingga terpaksa menempuh segala macam cara. Yakin bahwa guru tidak akan memeriksa tugas yang diberikan berdasarkan pengalaman sebelumnya sehingga bermaksud membalas dengan mengelabui guru yang bersangkutan. ${ }^{4}$

Dalam pengukuran pendidikan, bentuk tes yang paling sering digunakan adalah bentuk tes pilihan ganda, karena menyediakan cara yang efisien dan efektif. Namun demikian, dalam pelaksanaan tes dengan menggunakan soal-soal yang berben- 
tuk pilihan ganda menghadirkan suatu permasalahan yang sangat nyata dengan terjadinya kecurangan sangat besar. Salah satu bentuk kecurangan yang paling sering terjadi adalah copying answer. Masalah kecurangan peserta tes dalam menjawab soalsoal pilihan ganda bertahun-tahun telah menjadi perhatian para ahli di bidang educational measurement (penilaian pendidikan). Mereka mengembangkan metode statistik untuk mendeteksi siapa-siapa saja yang diduga melakukan kecurangan.

Kecurangan adalah bertindak tidak jujur atau tidak adil untuk mendapatkan keuntungan. Cizek mengemukakan bahwa perilaku curang dibagi dalam tiga kategori yaitu (1) memberi, mengambil, atau menerima informasi tertentu, (2) menggunakan suatu alat yang dilarang, (3) memanfaatkan kelemahan orang, prosedur, proses untuk mendapatkan keuntungan. Berdasarkan kedua definisi di atas, dapat disimpulkan bahwa kecurangan adalah suatu perbuatan yang dilakukan dengan cara-cara yang tidak baik untuk mendapatkan keuntungan. ${ }^{5}$

Perilaku menyontek bukan cara yang benar untuk memperoleh nilai tinggi. Perilaku copying answer menjadi masalah karena akan menimbulkan kekaburan dalam pengukuran kemampuan siswa, guru menjadi sulit untuk menentukan penilaian secara objektif. Nilai yang diperoleh tidak dapat membedakan antara siswa yang memperoleh nilai tinggi karena kemampuan dan penguasaannya terhadap materi dengan siswa yang memperolehnya karena menyontek. ${ }^{6}$

Sekarang praktik menyontek banyak dijumpai dalam dunia pendidikan, masyarakat pun cenderung menolerir dan menganggapnya sebagai hal yang wajar. ${ }^{7}$ Bahkan sering terdengar ungkapan bahwa menyontek adalah seni dalam sekolah, hal ini menjadi hal yang aneh dan tidak wajar jika ada orang yang tidak pernah menyontek selama hidupnya. Penelitian Schab menunjukkan 93\% siswa menyatakan bahwa menyontek merupakan sesuatu yang normal dalam pendidikan. ${ }^{8} \mathrm{Hal}$ ini menunjukkan bahwa persoalan menyontek menjadi sesuatu yang wajar dan merupakan hal yang biasa dilakukan oleh peserta tes.

Perilaku menyontek terjadi karena masyarakat memiliki pandangan bahwa prestasi belajar tercermin dari pencapaian nilai yang tinggi, sehingga membuat siswa terpaku untuk memperoleh nilai tinggi dengan cara apa pun. Masyarakat cenderung semakin permisif sehingga menyebabkan perilaku menyontek semakin sulit dihilangkan. Fakta-fakta di atas menunjukkan bahwa menyontek merupakan suatu permasalahan yang menarik untuk dikaji lebih lanjut dalam hal ini intensitas copying anaswer pada tes kemampuan matematika.

\section{PERMASALAHAN}

Berdasarkan latar belakang tersebut di atas, maka permasalahan yang akan diteliti adalah:

1. Bagaimana intensitas kecurangan yang dilakukan oleh peserta ujian sebelum, pada saat ujian berlangsung?

2. Bagaimana intensitas kecurangan yang dilakukan oleh peserta ujian pada saat ujian berlangsung? 
3. Bagaimana intensitas kecurangan yang dilakukan oleh peserta ujian ketika ujian berlangsung secara tiba-tiba?

\section{TINJAUAN PUSTAKA}

\section{Definisi Menyontek (Copying Answer)}

Masalah kecurangan peserta tes dalam menjawab soal-soal pilihan ganda bertahun-tahun telah menjadi perhatian para ahli di bidang penilaian pendidikan (educational measurement). Van de Linden \& Sotaridona mengemukakan tiga asumsi yang digunakan dalam statistik uji yang dikembangkan adalah bahwa seorang peserta tes akan menjawab suatu butir pertanyaan dengan tiga kemungkinan yaitu (1) peserta menjawab karena mengetahui. Jika seorang peserta tes mengetahui ítem, maka peserta tesebut akan menjawab benar. Artinya jika peserta tes memiliki akses ke sumber dan mendapatkan jawaban, maka jawaban tersebut diuji, jika jawaban peserta tesebut salah maka peserta tersebut tidak akan menyalin jawaban tetapi memilih jawaban sendiri. (2) peserta menjawab tes dengan menebak. Jika peserta ujian tidak mengetahui jawaban dari ítem tetapi memiki akses ke sumber, dia akan menerima jawaban dari sumber dan menyalin. dan (3) peserta menjawab tes karena menyalin jawaban dari peserta lain. Akan tetapi jika peserta tes tidak memiliki akses untuk menyontek maka peserta hanya akan memberikan jawaban dengan asumsi pertama dan kedua. Dengan demikian, untuk setiap ítem dengan jawaban salah dari sumber, copier dapat berada pada salah satu dari tiga keadaan yang mungkin, masing-masing ditandai dengan probabilitas yang berbeda untuk memilih alternatif yang sama yang dipilih oleh sumber. ${ }^{9}$

Menyontek merupakan tindakan kecurangan dalam tes melalui pemanfaatan informasi yang berasal dari luar secara tidak sah. ${ }^{10}$ Menyontek dapat didefinisikan sebagai perbuatan curang, tidak jujur, dan tidak legal dalam mendapatkan jawaban pada saat tes. ${ }^{11}$ Menyontek diartikan sebagai segala macam tindakan dalam ujian atau tes untuk memperoleh nilai secara tidak sah. ${ }^{12}$

Dengan demikian, menyontek dapat diartikan sebagai segala macam perbuatan curang, tidak, jujur, dan tidak legal untuk mendapatkan jawaban pada saat tes untuk memperoleh nilai secara tidak sah dengan memanfaatkan informasi dari luar.

\section{Intensitas dan Aspek-aspek Menyontek (Copying Answer)}

Intensi diartikan sebagai tujuan atau maksud seseorang untuk berbuat sesuatu. ${ }^{13}$ Intensi diartikan sebagai niat seseorang untuk melakukan perilaku didasari oleh sikap dan norma subjektif terhadap perilaku tersebut. Norma subjektif muncul dari keyakinan normatif akan akibat perilaku, dan keyakinan normatif akibat perilaku tersebut terbentuk dari umpan balik yang diberikan oleh perilaku itu sendiri. ${ }^{14}$ Selain itu, intensi dapat didefinisikan sebagai maksud, pamrih, keinginan, tujuan, suatu perjuangan guna mencapai satu tujuan, ciri-ciri yang dapat dibedakan dari proses-proses psikologi, yang mencakup referensi atau kaitannya dengan suatu objek. ${ }^{15}$ 
Merujuk pada definisi di atas, maka dapat dikatakan bahwa intensi merupakan niat atau keinginan seseorang untuk melakukan suatu perilaku demi mencapai tujuan tertentu yang didasarkan pada sikap dan keyakinan orang tersebut maupun keyakinan dan sikap orang yang memengaruhinya untuk melakukan suatu perilaku tertentu.

Aspek menyontek dapat diperoleh dari bentuk perilaku seseorang. Terdapat empat aspek perilaku menyontek sebagai berikut: (1) Perilaku (behavior), yaitu perilaku spesifik yang nantinya akan diwujudkan. Pada konteks menyontek, perilaku spesifik yang akan diwujudkan merupakan bentuk-bentuk perilaku menyontek yaitu menggunakan catatan jawaban sewaktu ujian/ulangan, mencontoh jawaban siswa lain, memberikan jawaban yang telah selesai pada teman, dan mengelak dari aturanaturan. (2) Sasaran (target), yaitu objek yang menjadi sasaran perilaku. Objek yang menjadi sasaran dari perilaku spesifik dapat digolongkan menjadi tiga, yaitu orang tertentu/objek tertentu (particular object), sekelompok orang/sekelompok objek ( $a$ class of object), dan orang atau objek pada umumnya (any object). Pada konteks menyontek, objek yang menjadi sasaran perilaku dapat berupa catatan jawaban, buku, telepon genggam, kalkulator, maupun teman. (3) Situasi (situation), yaitu situasi yang mendukung untuk dilakukannya suatu perilaku (bagaimana dan di mana perilaku itu akan diwujudkan). Situasi dapat pula diartikan sebagai lokasi terjadinya perilaku. Pada konteks menyontek, perilaku tersebut dapat muncul jika siswa merasa berada dalam kondisi terdesak, misalnya diadakan pelaksanaan ujian secara mendadak, materi ujian terlalu banyak, atau adanya beberapa ujian yang diselenggarakan pada hari yang sama sehingga siswa merasa kurang memiliki waktu untuk belajar. Situasi lain yang mendorong siswa untuk menyontek adalah jika siswa merasa perilakunya tidak akan ketahuan. Meskipun ketahuan, hukuman yang diterima tidak akan terlalu berat. (4) Waktu (time), yaitu waktu terjadinya perilaku yang meliputi waktu tertentu, dalam satu periode atau tidak terbatas dalam satu periode, misalnya waktu yang spesifik (hari tertentu, tanggal tertentu, jam tertentu), periode tertentu (bulan tertentu), dan waktu yang tidak terbatas (waktu yang akan datang). ${ }^{16}$

Aspek intensi memiliki tingkat spesifikasi, pada tingkat yang paling spesifik, seseorang berniat untuk menampilkan perilaku tertentu berkaitan dengan suatu objek tertentu, pada situasi dan waktu yang spesifik. Tingkat pertama adalah intensi global yang merupakan kecenderungan seseorang untuk menunjukkan rasa senang atau tidak senangnya yang terwujud dalam perilaku terhadap suatu objek. Intensi global dapat dilihat secara langsung dengan bertanya pada seseorang untuk mengindikasikan apakah orang tersebut bermaksud menunjukkan reaksi mendukung atau tidak mendukung suatu objek. Tingkat kedua adalah tingkat intensi kelompok (cluster). Pengukuran terhadap intensi ini dapat dilakukan dengan memberi pertanyaan yang bersifat umum. Tingkat yang ketiga, perilaku sudah berupa perilaku yang spesifik. Tingkat berikutnya, tingkat keempat, perilaku akan menjadi lebih spesifik dengan adanya situasi atau waktu yang tertentu. Tingkatan yang kelima, yang merupakan tingkatan paling spesifik, yaitu intensi untuk melakukan perilaku spesifik, terhadap objek yang spesifik, pada situasi dan waktu yang spesifik. 


\section{METODE PENELITIAN}

Penelitian ini dilakukan untuk mengetahui intensitas kecurangan dalam hal ini copying answer yang dilakukan oleh peserta tes sebelum pelaksanaan tes, selama pelaksanaan tes, dan jika tes dilaksanakan secara tiba-tiba. Yang menjadi sampel dalam penelitian ini adalah mahasiswa program studi pendidikan matematika semester I. Instrumen yang digunakan dalam penelitian ini berupa angket kuesioner untuk mengukur tingkat intensitas kecurangan yang dilakukan oleh mahasiswa sebelum pelaksanaan tes, selama pelaksanan tes, dan jika tes dilaksanakan secara tiba-tiba.

\section{HASIL DAN PEMBAHASAN}

Intensitas Cheating yang dilakukan oleh mahasiswa dikelompokkan dalam tiga bentuk yaitu: sebelum ujian, pada saat ujian, dan jika ujian dilaksanakan secara tibatiba. Hasil analisis yang dilakukan terhadap data intesitas nyontek yang dilakukan oleh mahasiswa disajikan sebagai berikut:

\section{Deskripsi Intensitas Copying Answer Sebelum Pelaksanaan Tes}

Berdasarkan hasil analisis yang dilakukan, diperoleh informasi bahwa intensitas menyontek mahasiswa sebelum pelaksanaan ujian masuk dalam kategoti "TIDAK INGIN" dengan presentase sebesar 39\%. Hal ini menunjukkan bahwa tidak ada keingingan mahasiswa untuk melakukan nyontek sebelum ujian.

Gambar 1. Persentasi Intensitas Menyontek Sebelum Pelaksanaan Ujian

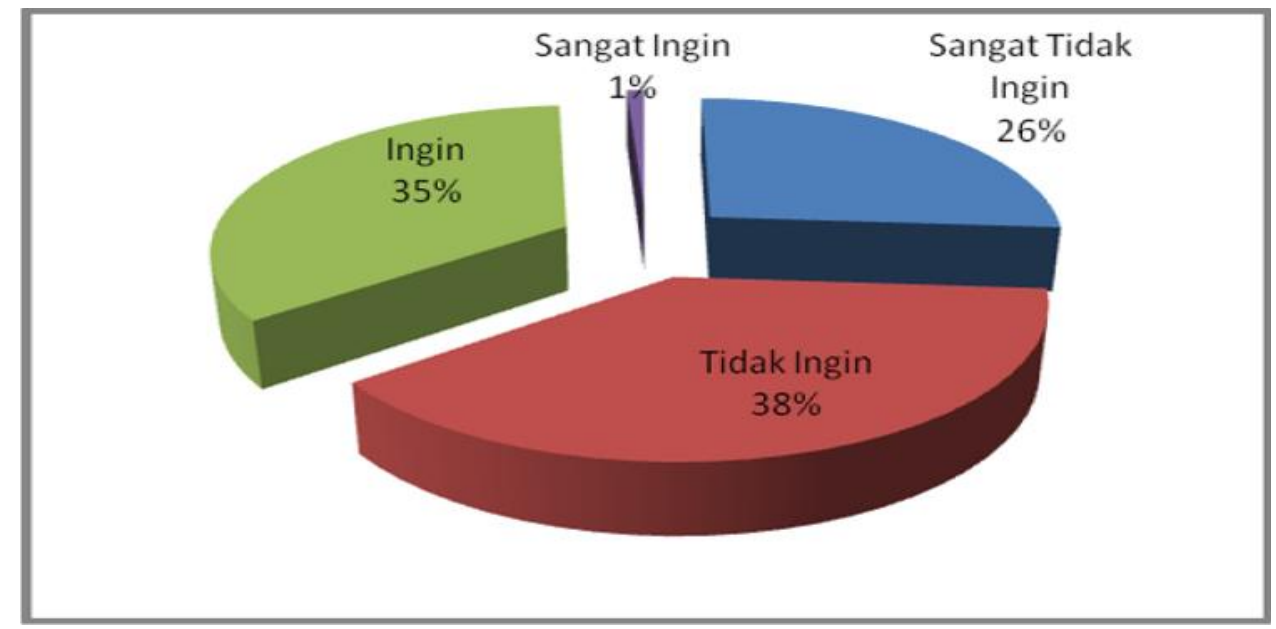

Deskripsi Intensitas Copying Answer Saat Pelaksanaan Tes

Hasil analisis menunjukkan bahwa intensitas menyontek mahasiswa saat pelaksanaan ujian masuk dalam kategori "SANGAT TIDAK INGIN" dengan presentase sebesar 51\%. Hal ini menunjukkan bahwa tidak ada keingingan mahasiswa untuk melakukan nyontek saat ujian. 
Gambar 2. Persentasi Intensitas Menyontek Saat Pelaksanaan Ujian

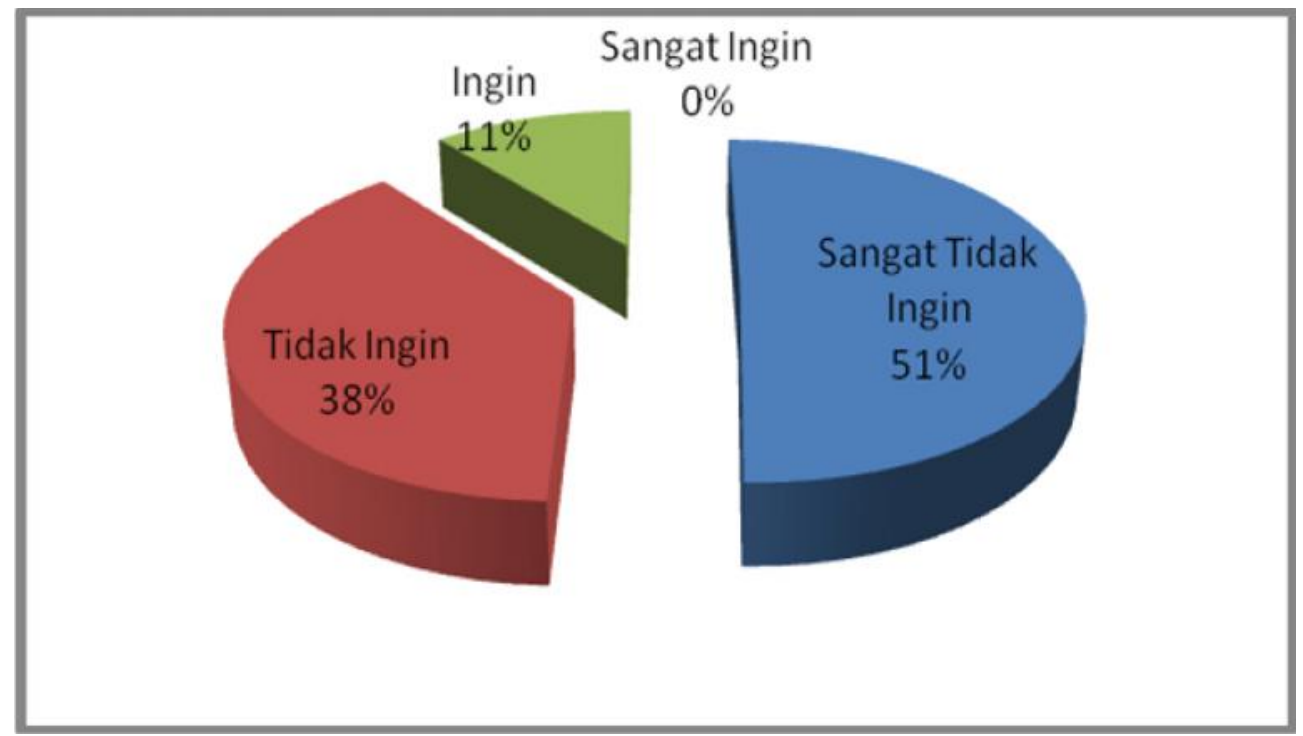

\section{Deskripsi Intensitas Copying Answer Jika Ada Tes Secara Tiba-Tiba}

Analisis yang dilakukan terhadap respon mahasiswa yang berkaitan dengan intensitas menyontek jika tes dilakukan secara tiba-tiba menunjukkan bahwa mahasiswa tersebut cenderung untuk menyontek dengan berada pada kategori "INGIN" sebesar $48 \%$. Hal ini dapat dilihat pada gambar berikut:

Gambar 2. Persentasi Intensitas Menyontek Pelaksanaan Ujian Tiba-Tiba

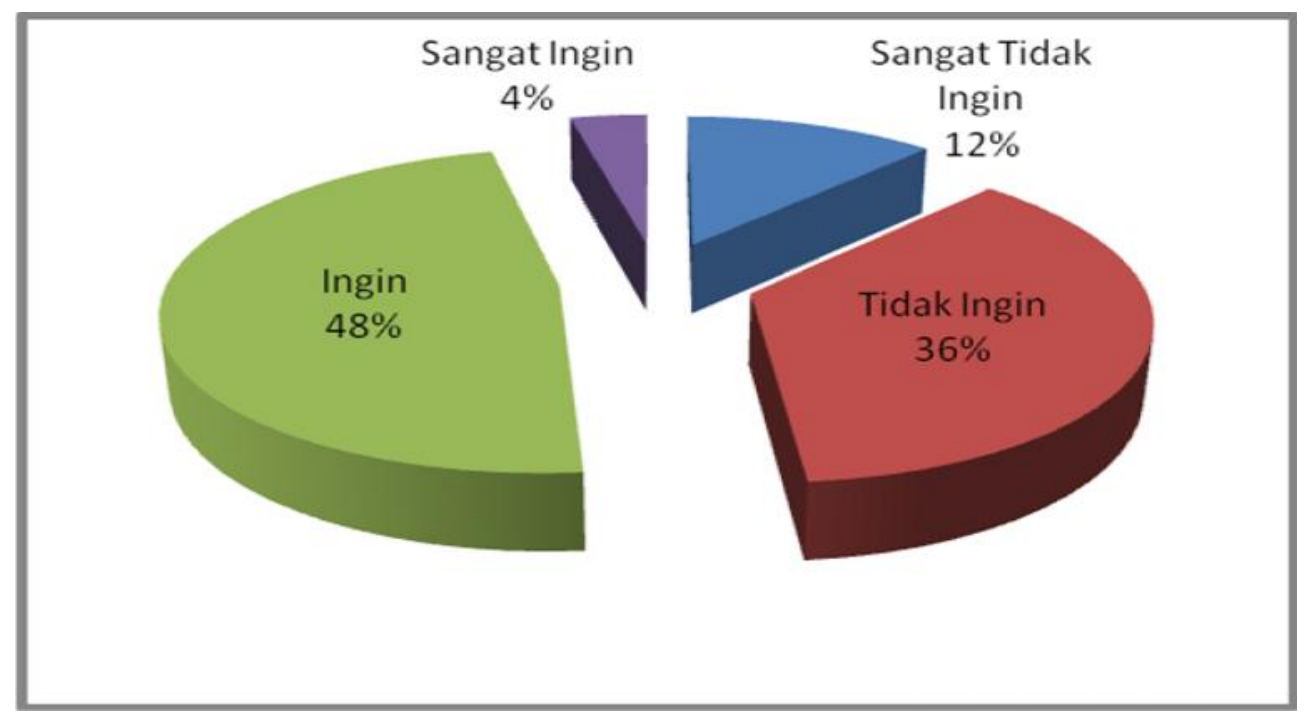

Secara akumulatif masing-masing proses intensitas nyontek dapat dilihat pada tabel dan grafik berikut: 


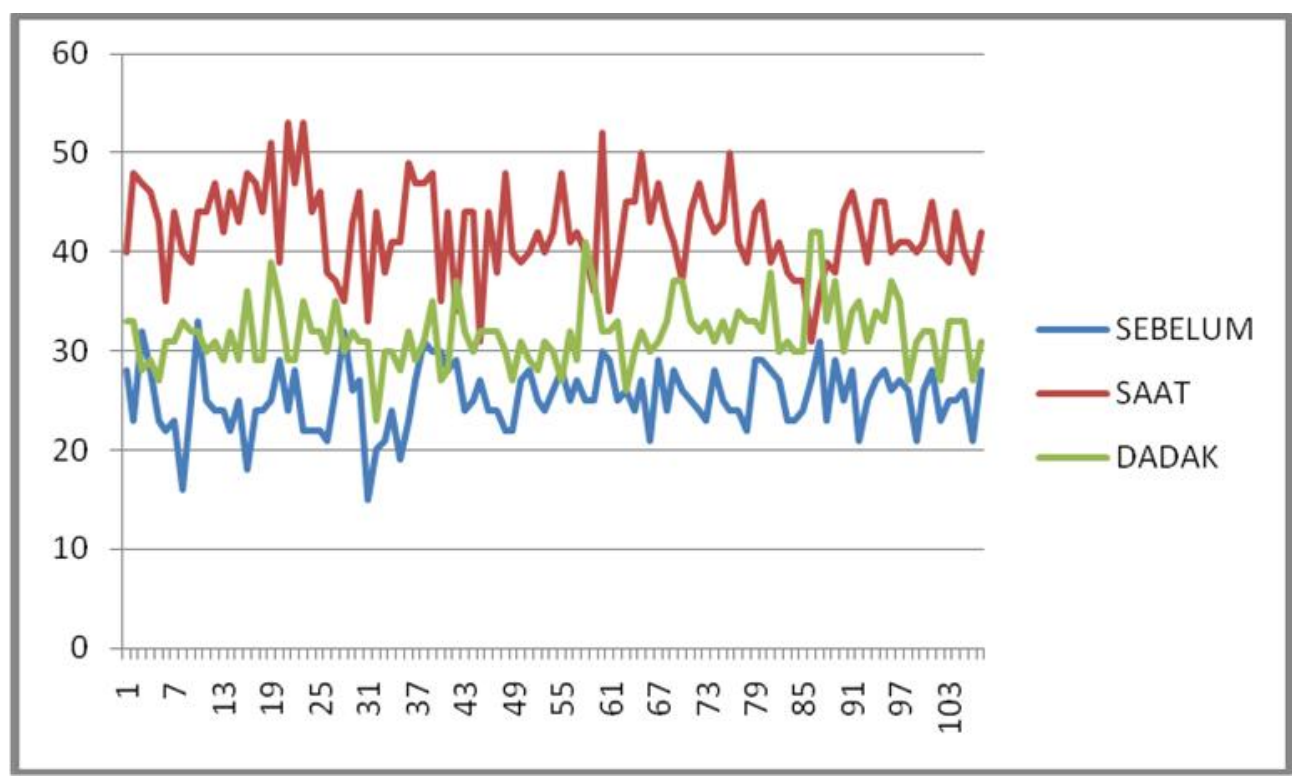

Berdasarkan gambar di atas, nampak bahwa peserta tes memiliki intensitas kecurangan yang sangat tinggi pada saat ujian berlangsung. Hal ini ditandai dengan tingginya nilai intensitas menyontek yang dilakukan oleh peserta tes.

\section{SIMPULAN}

Kecurangan (cheating) dalam pelaksanaan tes menjadi masalah yang perlu mendapatkan perhatian khusus, hal ini karena kecurangan sudah dianggap sebagai sesuatu yang biasa dan bahkan dianggap sebagai suatu seni oleh sebahagian peserta tes. Menyontek (copying answer) adalah salah satu bentuk kecurangan merupakan suatu bentuk perilaku yang dilakukan oleh peserta tes. Hasil penelitian tentang intensitas menyontek yang dilakukan oleh peserta tes menunjukkan bahwa intensitas peserta tes untuk melakukan menyontek sangat tinggi ketika peserta tes mengikuti ujian (pada sat tes berlangsung), diikuti jika tes dilakukan secara mendadak dan sebelum pelaksanaan tes.

\section{CATATAN AKHIR:}

1. M. A. Steiner, Cheating in School, The School Review, 40(7), 535 - 546, 1932, p. 536.

2. Ann Bushway \& William R. Nash, School Cheating Behavior, Review of Educational Research, 47 (4), 623 - 632. 1977, p. 626.

3. Yulia Poltorak, Cheating Behavior among Students of Four Moscow Institutes, Higher Education, 30, 225 - 246. 1995. p. 226 - 227.

4. William H. Angoff, The Development of Statistical Indices for Detecting Cheaters, Journal of The American Statistical Association, 69(345), 44 - 49. 1974. p. 44.

5. G. J. Cizek, Cheating on tests: How to do it, detect it, and prevent it, Englewood Cliffs, NJ: Lawrence Erlbaum, 1999, p.138-139.

6. Indarto, Y., dan Masrun. Hubungan Antara Orientasi Penguasaan dan Orientasi Performansi dengan Intensi Menyontek. Sosiosains, 17(3), 411-421. 2004. p.411-413. 
7. Haryono, W., Hardjanta, G., dan Eriyani ,P. Perilaku Menyontek Ditinjau dari Persepsi terhadap Intensitas Kompetisi dalam Kelas dan Kebutuhan Berprestasi. Psikodimensia. Kajian Imiah Psikologi, 2(1). 10-16. 2001. p.10.

8. Sujana, Y.E., dan Wulan, R. Hubungan Antara Kecenderungan Pusat Kendali dengan Intensi Menyontek. Jurnal Psikologi, 21(2). 1-7. 1994. p. 3.

9. Wim J. van der Linden \& Leonardo Sotaridona. A Statistical Test for Detecting Answer Copying on Multiple-Choice Tests. Journal of Educational Measurement, 41(4), 361 - 377. 2004. p. 362.

10. Sujana, Y.E., dan Wulan, R. Hubungan Antara Kecenderungan Pusat Kendali dengan Intensi Menyontek. Jurnal Psikologi, 21(2). 1-7. 1994. p. 1.

11. Y. Indarto, dan Masrun, Hubungan Antara Orientasi Penguasaan dan Orientasi Performansi dengan Intensi Menyontek, Sosiosains, 17(3), 411-421. 2004, h. 411.

12. W. Haryono, G. Hardjanta, dan P. Eriyani, Perilaku Menyontek Ditinjau dari Persepsi terhadap Intensitas Kompetisi dalam Kelas dan Kebutuhan Berprestasi, Psikodimensia, Kajian Imiah Psikologi, 2(1). 10-16, 2001, h. 10.

13. K. Kartono dan D. Gulo, Kamus Psikologi, Bandung: CV. Pionir Jaya, 1987, h. 26.

14. M. Fishbein dan I. Ajzen, Belief, Attitude, Intention and Behavior: An Introduction to Theory and Research, California: Addison-Wesley Publishing, 1975, h. 288.

15. J. P. Chaplin, Kamus Lengkap Psikologi, Jakarta: PT. Raja Grafindo Persada, 1999, h. 254.

16. M. Fishbein dan I. Ajzen, op.cit., h. 292.

\section{DAFTAR PUSTAKA:}

Angoff, W.H., The Development of Statistical Indices for Detecting Cheaters, Journal of The American Statistical Association, 69(345), 44 - 49, 1974.

Bushway, A. \& Nash, W. R., School Cheating Behavior, Review of Educational Research, 47(4), $623-632,1977$.

Cizek, G. J., Cheating on tests: How to do it, detect it, and prevent it, Englewood Cliffs, NJ: Lawrence Erlbaum, 1999.

Chaplin, J.P., Kamus Lengkap Psikologi, Jakarta: PT. Raja Grafindo Persada, 1999.

Fishbein, M., dan Ajzen, I., Belief, Attitude, Intention and Behavior:: An Introduction to Theory and Research, California: Addison-Wesley Publishing, 1975.

Haryono, W., Hardjanta, G., dan Eriyani, P., Perilaku Menyontek Ditinjau dari Persepsi terhadap Intensitas Kompetisi dalam Kelas dan Kebutuhan Berprestasi, Psikodimensia. Kajian Imiah Psikologi, 2(1). 10-16. 2001.

Indarto, Y., dan Masrun, Hubungan Antara Orientasi Penguasaan dan Orientasi Performansi dengan Intensi Menyontek, Sosiosains, 17(3), 411-421. 2004.

Kartono, K., dan Gulo, D., Kamus Psikologi, Bandung: CV. Pionir Jaya, 1987.

Poltorak, Y., Cheating Behavior among Students of Four Moscow Institutes, Higher Education, 30, $225-246,1995$.

Steiner, M. A., Cheating in School, The School Review, 40(7), 535 - 546, 1932.

Sujana, Y.E., dan Wulan, R., Hubungan Antara Kecenderungan Pusat Kendali dengan Intensi Menyontek, Jurnal Psikologi, 21(2). 1-7, 1994.

van der Linden, W.J., \& Satoridona, L. A., Statistical Test for Detecting Answer Copying on Multiple-Choice Tests, Journal of Educational Measurement, 41(4), 361 - 377. 2004. 